Obituaries

\section{Professor Elisabeth Goldschmidt}

Elisabeth Goldschmidt, one of the founders of genetics in Israel, died on May 6, 1970. She was born in 1912 in Frankfurt/Main where she went to school and finished her premedical examinations in 1933. Subsequently she took a zoology degree at the University of London in 1936 and then settled in Jerusalem. In 1942 she took her $\mathrm{PhD}$ at the Hebrew University with a thesis on the cytology of chironomids. During her long career at that university, she successively became instructor, lecturer, associate professor and finally full professor of genetics.

Dr Goldschmidt's three chief interests were the cytology of arthropods, the population genetics of Drosophila and, in later years increasingly, human genetics. Dr Goldschmidt soon realized the unique opportunities which the immigrant groups in the new state of Israel offered for providing information about genetically distinct groups which can be expected to merge within the next few generations. Usually, the genetic structure of a population is explained as the result of mixture between past populations whose genetical composition is at best conjectural. The mixture which is about to take place in Israel will be an observed process if the genetical composition of the various component populations is ascertained before the populations merge.

Much of Dr Goldschmidt's own work in the human field is summarized in The Genetics of Migrant and Isolated Populations, after a symposium which she organized in 1961. On that occasion, about 150 geneticists from fifteen countries discussed the genetics of the Jewish immigrant groups; work from her own department included studies on blood groups, haptoglobins and transferrins, G6PD deficiency, thalassaemia, colour blindness and taste sensitivity and isoniazid inactivation, as well as more anthropological studies (dermatoglyphics, osteology). Dr Goldschmidt also appeared as a co-author of many biochemical, clinical and population-genetical contributions.

\section{Announcements}

\section{University News}

Mr Hugh Rogers has been re-elected chairman of council of the University of Bristol. Professors A. I. Darling, S. Körner and E. W. Yemm are to be provice-chancellors.

A gift of $\$ 500,000$ from the Foundation for Emotionally Disturbed Children has enabled the University of Chicago to establish an endowed professorship in honour of Professor Bruno Bettelheim, Stella M. Rowley distinguished service professor of education, director of the Sonia Shankman orthogenic school and professor of psychiatry and psychology in the University of Chicago.

Professor George A. Sim, University of Sussex, has been appointed to the Gardiner chair of chemistry in the University of Glasgow, in succession to Professor $J$. Monteath Robertson, who is retiring.

Dr Henry F. Allen, chief of the Department of Ophthalm. ology at the Massachusetts Eye and Ear Infirmary and chairman of the Department of Ophthalmology at Harvard Medical School, has been appointed Henry Willard Williams clinical professor of ophthalmology at Harvard University, in succession to Dr David G. Cogan. Dr Cogan is to be the first holder of the newly established professorship of ophthalmology in the Faculty of Medicine at Harvard. Dr Julius B. Richmond, dean of the Medical Faculty of the State University of New York at
Syracuse, has been appointed professor of child psy. chiatry and human development at Harvard University, director of the Judge Baker Guidance Center, Boston, and psychiatrist-in-chief at the Children's Hospital Medical Center.

Rodney W. Nichols has been appointed director of program planning at the Rockefeller University, and special assistant to the president.

Dr M. R. P. Hall, University of Newcastle upon Tyne, has been appointed to the chair of geriatric medicine in the University of Southampton. Also at Southampton, Dr J. L. Gibbons, University of Newcastle upon 'Tyne, has been appointed to the chair of psychiatry, Dr M. R. Alderson, University of Manchester, has been appointed to the chair of Medical Information Science, and Dr W. Brumfitt, St Mary's Hospital Medical School, University of London, has been appointed to the chair of pathology.

\section{Appointments}

Charles W. Harper has been appointed special assistant to the director for interagency affairs at NASA's Ames Research Center in California.

Dr G. A. H. Elton, director of research to the Flour Milling and Baking Research Association, has been appointed chief scientific adviser (food) to the Ministry of Agriculture, Fisheries and Food

Dr Rudd Jones, scientific adviser to the secretary of the ARC and joint secretary of the ARC Research Committee on Toxic Chemicals, has been appointed director of the Glasshouse Grops Research Institute in succession to Mr F. W. Toovey, who retires in March 1971.

In the new Soviet government (First Session of the Eighth Convocation of the Supreme Soviet of the USSR), ministerial appointments include: A. V. Sidorenko (Minister of Geology), B. V. Petrovskii (Minister of Health), K. V. Rudnev (Minister for Automation) and M. A. Prokof'ev (Minister of Education). Other appointments include V. N. Starovskii (head of Central Statistical Control) and A. V. Georgiev (chairman of the Commission for the Conservation of Nature).

\section{Miscellaneous}

His Royal Highness the Duke of Edinburgh has agreed to become patron of the Research and Development Society. The first honorary president of the Society will be Sir James Taylor, chairman of the Royal Society of Arts.

Dr Anne Anastasi of Fordham University is to be president-elect of the American Psychological Association. The present president-elect, Dr Kenneth B. Glark, City University of New York, will succeed Dr George W. Albee of Case Western Reserve University as president in October.

Dr A. C. Neish, director of the Atlantic Regional Laboratory of the National Research Council of Canada, is the first recipient of the newly established gold medal award of the Canadian Society of Plant Physiologists. Dr Neish is cited for his outstanding contributions in the study of fermentation processes and the biosynthesis of plant cell wall components and, more recently, in the cultivation of crop plants from the sea.

The premises of the Royal Cork Yacht Club, which celobrates its 250th anniversary this year, have been purchased by University Gollege, Cork, for the development of a marine biology station. The sito is particularly appropriate because John Vaughan Thompson, widely regarded as the father of marine biology and the first man to use a plankton net, is believed to have been associated with the club while surgeon to the British Forces in Southern Ireland during 1816-35. 